\section{LETTERS TO THE EDITOR}

\section{A study on the possible association of dysfunctional uterine bleeding with bacterial vaginosis, mycoplasma, ureaplasma, and Gardnerella vaginalis}

EdIToR, - A number of studies in the recent years have shown that bacterial vaginosis or its associated micro-organisms mycoplasma/ ureaplasma may be associated with various obstetric and gynaecological complications such as pelvic inflammatory disease and infertility, ${ }^{1}$ premature rupture of membranes and preterm labour, ${ }^{2}$ plasma cell endometritis, ${ }^{3}$ non-specific urethritis in male partners, ${ }^{4}$ and in our previous study ${ }^{5}$ we showed colonisation of the endometrium by mycoplasma and ureaplasma in patients with bacterial vaginosis

The purpose of this study was to see if there is any association between dysfunctional uterine bleeding (DUB) and mycoplasma, ureaplasma, and/or bacterial vaginosis.

Ten patients, all with dysfunctional uterine bleeding admitted for abdominal hysterectomy, were recruited for the study. Patients were between 38 and 48 years (mean age 44 ) and all except one were parous. Appropriate ethics committee approval and informed consents were taken.

A detailed history was taken, particularly obstetrics and gynaecological, and any history of bacterial vaginosis or troublesome vaginal discharge. A preoperative high vaginal swab for microscopic diagnosis of bacterial vaginosis was taken. At operation, the endometrial cavity was opened by splitting the anterior wall of the uterus and an endometrial swab and biopsy were taken for microbial culture and scanning electron microscopy for mycoplasma, ureaplasma, and Gardnerella vaginalis.

None of the patient had any history of bacterial vaginosis, troublesome vaginal discharge, or any obstetric or gynaecological complications. Microscopic examination of the high vaginal swabs were all normal except one with possible bacterial vaginosis. Microbial culture and scanning electron microscopy showed no mycoplasma, ureaplasma, or Gardnerella vaginalis.

Although there is definite association of colonisation of the endometrium by mycoplasma and ureaplasma in patients with bacterial vaginosis, as we showed in our previous study, this study did not show any association of DUB with bacterial vaginosis, Gardnerella vaginalis, mycoplasma, or ureaplasma. Any significant association of DUB and bacterial vaginosis appears unlikely, as the age group of the majority of patients with DUB, as in this study, is also different from the age group for bacterial vaginosis.

B BHATTACHARJEE A K GHOSH

Department of Genitourinary Medicine, Arrowe Park Hospital, Upton, Wirral, Merseyside, L49 5PE A MURRAY Department of Obstetrics and Gynaecology
A E MURRAY Department of Medical Microbiology

Correspondence to: Dr Bhattacharjee

1 Sweet RL. Role of bacterial vaginosis in pelvic inflammatory disease. Clin Infect Dis 1995;20(suppl 2):s271-5.

2 Hay PE, Lamont, Taylor-Robinson D, et al. Abnormal bacterial colonisation of genital tract and preterm delivery and late miscarriage. BMF 1994;308:295-5.

3 Korn AP, Bolan G, Padian, et al. Plasma cell endometritis in women with bacterial vaginosis. Obstet Gynaecol 1995;85:38790 .

4 Keane FFA,Thomas B, Renton A, et al. Investigation into possible role of bacterial vaginosis in non-gonococcal urethritis. Genitourin Med in non-gonococca

5 Bhattacharjee B, Sunderland D, Herrington S, et al. Scanning electron microscopy of endometrial biopsy of patients with bacterial vaginosis shows morphology resemblimg mycoplasma/ureaplasma. Sex Transm Inf 1999;

Accepted for publication 7 June 2000

Ethnicity and country of acquisition of HIV in the current Leicester genitourinary medicine clinic cohort

EDIToR,-We have surveyed the regular HIV infected attenders in the Leicester genitourinary medicine (GUM) HIV cohort; there are currently 60 men and 16 women. Twenty five per cent are black African and $13 \%$ are of Indian/Pakistani/Bangladeshi stock, while $62 \%$ are white. This amounts to 19 of 8258 black Africans in the Leicestershire total county population (which includes Leicester central district) being HIV positive. Forty seven of 771181 white people and 10 of 77537 Asians in the Leicestershire total county population were also HIV positive (Leicester City Council, from 1991 census figures, 2000, personal communication).

For acquisition of HIV related to ethnicity, the results are as displayed in table 1 .

In 1997, of those with heterosexually transmitted $\mathrm{HIV}^{1}$ in the United Kingdom, $3.3 \%$ were black Caribbeans, $49 \%$ were black African, with $33 \%$ being white, and $2.3 \%$ were Asian.

In 1999, the Communicable Disease Report $^{2}$ stated that, of female HIV infected people in England and Wales, 32\% were white people and $49.5 \%$ were black Africans, and $2.7 \%$ were black Caribbeans, and $1.3 \%$ were south Asians.

Compared with the latter England and Wales figures, Leicester appears to have a moderate underrepresentation of black Africans with HIV, and a moderate overrepresentation of Asians in its cohort. This latter figure is to be expected because Leicester's Asian population is $23.7 \%$ of the total population of the city (Leicester City Council, 1991 census figures, 2000, personal communication). However, the Asian figure

Table 1 Table of ethnicity in relation to country of acquisition of HIV, as found in the Leicester genitourinary medicine clinic HIV cohort, and assessed in April 2000

\begin{tabular}{lllll}
\hline \multirow{2}{*}{ Country of acquisition } & \multicolumn{2}{l}{ Ethnicity } & \\
\cline { 2 - 4 } & Asian & African & White & Total (\%) \\
\hline Asia & $2(3 \%)$ & $2(3 \%)$ & $2(3 \%)^{\star}$ & $9 \%$ \\
Africa & $2(3 \%)$ & $15(25 \%)$ & $2(3 \%)$ & $31 \%$ \\
UK & $2(3 \%)$ & $2(3 \%)$ & $43(54 \%)$ & $60 \%$ \\
Total & $9 \%$ & $31 \%$ & $60 \%$ & $100 \%$
\end{tabular}

`Thailand.

Ping LH, Nelson JA, Hoffman IH. Charac- is not that high pro rata, possibly because cultural factors prohibit sex outside marriage.

Quinn et $a l^{3}$ have shown recently that viral load is the chief predictor of the risk of heterosexual transmission of HIV-1, and that transmission is rare among people with levels of less than 1500 copies of HIV-1 RNA per $\mathrm{ml}$.

It may be that HAART (highly active antiretroviral therapy) for HIV infected people has caused transmission to be low in the United Kingdom but, as Cohen says, such a theory has not been proved.

The viral subtype dominant in parts of Africa (clade C), has unique properties that favour sexual transmission. ${ }^{5}$ Other factors that make Africans more susceptible to HIV than those who live in more developed countries include lack of host factors that reduce infection risk; the plasma HIV-1 RNA level in seropositive people being higher in sub-Saharan Africans; the lack of mutations in the gene for chemokine receptor 5; circumcision status, with most men in Africa being uncircumcised; and the high prevalence of ulcerative sexually transmitted diseases. ${ }^{4}$ Some of these factors will operate for Asian patients born in

Thus, ethnicity and country of acquisition of HIV in Leicester as elsewhere, is a reflection of interwoven, genetic, environmental and behavioural, political, and geographical factors. ${ }^{4}$ Therefore, we cannot just examine nationality in isolation when considering HIV epidemiology. Travellers from Britain to Thailand, the Philippines, India, and Africa especially should be forewarned of the risks of sex and healthcare needle exposure and/or blood transfusions in all travel medicine consultations.

DEREK T P EVANS CENT C RILEY PETER G FISK

Department of Genito-urinary Medicine, Leicester Royal Infirmary, Leicester LE1 $5 \mathrm{WW}$

Correspondence to: Dr Evans

Communicable Disease Report. 1999;9(No 22): 200.

Communicable Disease Report. 1999;9(No 26): 236

Quinn TC, Wawer MJ, Sewankambo N, et al. Viral load and heterosexual transmission of human immunodeficiency virus type I. N Engl f Med 2000;342:921-9.

4 Cohen MS. Preventing sexual transmission of -new idea from sub-Saharan Africa. $N$ Engl f Med 2000;342:970-2. terisation of V3 sequence heterogenicity in sub-type $\mathrm{C}$ human immunodeficiency virus type I isolates from Malawi underrepresentation of X4 variants. F Virol 1999;73: 6271-81.

Accepted for publication 14 June 2000 


\section{Detection of 14-3-3 brain protein in cerebrospinal fluid of HIV infected patients}

EDIToR,- - The 14-3-3 proteins are a group of highly conserved proteins involved in intracellular signalling. Detection of 14-3-3 brain protein has been described in cerebrospinal fluid (CSF) of patients with transmissible spongiform encephalopathies including both sporadic and variant Creutzfeldt-Jakob disease. ${ }^{12}$ False positive results have been reported in conditions producing (sub)acute neuronal destruction, including herpes simplex encephalitis, ischaemic stroke, multi-infarct dementia, and paraneoplastic syndromes. ${ }^{1-3}$ We postulated that 14-3-3 brain protein may be detected in CSF from patients with HIV associated dementia complex (HADC) as this condition is characterised neuropathologically by a giant cell encephalitis, leucoencephalopathy, astrogliosis and neuronal loss.

We prospectively studied 17 HIV antibody positive patients (14 men) aged 27-60 (median 37) years, with CD4 counts of 0-220 (median 20) cells $\times 10^{6} / 1$, who underwent lumbar puncture for investigation of HADC (six patients), staging of lymphoma (five patients), or investigation of other conditions (six patients): epilepsy (two), cervical radiculopathy (one), chronic demyelinating polyradiculopathy (one), CMV encephalitis (one), self limiting headache (one). Of those with HADC, the severity of dementia assessed using Memorial Sloan-Kettering criteria, ${ }^{4}$ was mild in two and moderate in four. The degree of atrophy on cranial magnetic resonance imaging, used as a marker of neuronal loss ${ }^{5}$ was mild in four and moderate in two. Clinical details of those with lymphoma are given in table 1. At each lumbar puncture an aliquot of CSF $(250 \mu \mathrm{l})$ was frozen immediately at $-20^{\circ} \mathrm{C}$ and stored for subsequent $14-3-3$ protein analysis.

CSF was routinely processed as described previously. ${ }^{6}$ Detection of 14-3-3 protein was done without knowledge of the patient's diagnosis, using a technique described by Hsich et al, ${ }^{1}$ modified to use anti-14-3-3 $\gamma$ polyclonal rabbit antibody.

In 14 of 17 patients CSF was negative for 14-3-3 protein. Of the three with detectable 14-3-3 protein in CSF, all had lymphoma but only one had CNS disease, the other two had only extraneural disease (table 1). These data, although from a small study population, suggest that detection of 14-3-3 protein in CSF is not useful for diagnosis of HADC. Detectable 14-3-3 protein has previously been reported in a non-HIV infected patient with CNS lymphoma, ${ }^{3}$ so this observation in our patient is not unique, although brain necrosis from coexisting cerebral toxoplasmosis provides an alternative explanation. Of the two patients with extraneural lymphoma and detectable 14-3-3 protein in CSF, one had EBV DNA in CSF and so was at high risk of developing cerebral lymphoma. This possibility could not be confirmed as necropsy was not performed. In neither of the latter two patients was there a CSF pleocytosis, so contamination by 14-3-3 protein derived from peripheral blood leucocytes is unlikely. In the final case the absence of limbic encephalitis or cerebellar degeneration ${ }^{3}$ makes it difficult to ascribe the finding to a paraneoplastic process.

R F MILLER

Department of Sexually Transmitted Diseases, Royal Free and University College Medical School, Mortimer Market Centre, Mortimer Market, Off Capper Street, London WC1E 6AU, UK

A J E GREEN G GIOVANNONI E J THOMPSON

Department of Neuroimmunology, Institute of Neurology, National Hospital for Neurology and Neurosurgery, Queen Square, London WC1N 3BG Correspondence to: Dr Miller

1 Hsich G, Kenney K, Gibbs C J, et al. The 14-3-3 brain protein in cerebrospinal fluid as a marker for transmissible spongiform encephalopathies. N Engl f Med 1996;335:924-30

2 Zeidler M, Stewart GE, Barraclough CR, et al. New variant Creutzfeldt-Jakob disease: neurological features and diagnostic tests. Lancet 1997;350:903-7

3 Saiz A, Graus F, Dalmau J, et al. Detection of 14-3-3 brain protein in the cerebrospinal fluid of patients with paraneoplastic neurological disorders. Ann Neurol 1999;46: neurologic

4 Price RW, Brew BJ. The AIDS dementia complex. F Infect Dis 1988;158:1079-83.

5 Miller RF, Lucas SB, Hall-Craggs MA, et al. Comparison of magnetic resonance imaging with neuropathological findings in the diagnosis of HIV and CMV associated CNS disease in AIDS. I Neurol Neurosurg Psychiatry 1997;62: 346-51.

6 Miller RF, Hall-Craggs MA, Costa DC, et al. Magnetic resonance imaging, thallium-201 SPET scanning and laboratory analyses for discrimination of and laboratory analyses for discrimination of cerebral lymphoma and toxopasmosi.

Accepted for publication 14 July 2000
Hepatitis $B$ vaccination in a high risk MSM population: the need for vaccine education

EdIToR,-Estimates of the prevalence of hepatitis $\mathrm{B}$ virus (HBV) markers among men who have sex with men (MSM) range from $5 \%$ to $81 \%$, and the prevalence of HBV surface antigen varies from $1 \%$ to $11 \% .^{12}$ Despite a safe and effective vaccine against HBV, sexually active MSM are not vaccinated adequately..$^{2-5}$ Few empirical data describe the factors associated with $\mathrm{HBV}$ vaccination among MSM. We conducted a study to identify correlates of HBV vaccination among MSM that could inform future interventions designed to enhance $\mathrm{HBV}$ vaccination

Data were collected at two male "gay" bars in Birmingham, Alabama, USA, using a brief, self administered questionnaire. Of 130 bar patrons, our sample consisted of 111 respondents who identified themselves as MSM and knew their vaccination status. Their average age was 31 years with a range of $18-48$ years. The sample was disproportionately white $(91.9 \%) ; 42 \%$ reported being vaccinated for $\mathrm{HBV}$.

Based on bivariate associations nine characteristics were significantly associated with HBV vaccination - age; condom use; factual knowledge of hepatitis; HBV knowledge; HCV knowledge; HBV vaccination knowledge; number of sources for information about hepatitis; information from a physician; and information from professional training. Two factors retained significance when adjusting for all other factors in a multivariate logistic regression model: respondents' HBV vaccination knowledge $(\mathrm{OR}=10.18 ; 90 \% \mathrm{CI}$ $=4.0-25.37, \mathrm{p}=0.0001)$ and their frequency of condom use $(\mathrm{OR}=6.1 ; 90 \% \mathrm{CI}=2.54$ $14.67, \mathrm{p}=0.0007)$. The predictive power of the model $\left(\chi^{2}=42.33 ; \mathrm{p}=0.0001\right)$ was high, correctly classifying $76.4 \%$ of the respondents into their actual vaccination status categories $(p=0.0001)$. These findings suggest that respondents with high HBV vaccination knowledge and condom use are significantly more likely to have been vaccinated against HBV.

There is need to enhance awareness and facilitate vaccination among this high risk population for $\mathrm{HBV}$ infection; $32 \%$ reported having no information about hepatitis. Many respondents reported engaging in behaviours that put them and their sexual partners at risk for HBV infection; $95.5 \%$ and $30.6 \%$ reported using a condom less than $50 \%$ of the

Table 1 Clinical features, results of CSF brain protein detection, and outcome in patients with lymphoma

\begin{tabular}{|c|c|c|c|c|c|}
\hline \multirow[b]{2}{*}{ Patient } & \multirow[b]{2}{*}{ Type of lymphoma } & \multirow[b]{2}{*}{$\begin{array}{l}\text { No of } \\
\text { lumbar } \\
\text { puncture }\end{array}$} & \multicolumn{2}{|l|}{ CSF } & \multirow[b]{2}{*}{ Outcome } \\
\hline & & & $\begin{array}{l}\text { Interval between } \\
\text { lumbar puncture } \\
\text { (weeks) }\end{array}$ & $\begin{array}{l}14-3-3 \\
\text { detection }\end{array}$ & \\
\hline \multirow[t]{2}{*}{1} & \multirow[t]{2}{*}{ Primary CNS } & 1 & \multirow[b]{2}{*}{11} & No & Died 2 weeks after second lumbar puncture \\
\hline & & 2 & & & Necropsy showed also cerebral toxoplasmosis \\
\hline \multirow[t]{2}{*}{2} & \multirow[t]{3}{*}{ Primary CNS } & 1 & & No & Died 2 weeks after second lumbar puncture \\
\hline & & & 3 & & Necropsy confirmed diagnosis \\
\hline & & 2 & & No & \\
\hline 3 & Primary CNS & 1 & NA & No & Died 3 weeks later. No necropsy \\
\hline 4 & Systemic, disseminated extraneural & 1 & NA & Yes & $\begin{array}{l}\text { Died } 6 \text { weeks later. Cranial MR scan normal but EBV DNA } \\
\text { detected in cell free CSF }\end{array}$ \\
\hline 5 & Systemic, extra neural & 1 & NA & Yes & $\begin{array}{l}\text { Alive. Cranial MR scan normal. Treated with local RT and } \\
\text { HAART. No lymphoma recurrence after } 39 \text { months follow up }\end{array}$ \\
\hline
\end{tabular}

$\mathrm{CNS}=$ central nervous system $. \mathrm{NA}=$ not applicable. $\mathrm{EBV}=$ Epstein - Barr virus. $\mathrm{CSF}=$ cerebrospinal fluid. $\mathrm{MR}=$ magnetic resonance. $\mathrm{RT}=$ radiotherapy. $\mathrm{HAART}$

$=$ highly active antiretroviral therapy. 
time during oral and anal intercourse, respectively. Given that HBV transmission usually results from mucous membrane exposure to infectious body fluids, including semen, ${ }^{6}$ the failure to vaccinate this high risk population is a missed opportunity to prevent disease.

Our findings suggest that MSM lack information about HBV risk and vaccination, and are engaging in behaviours that put them at risk for $\mathrm{HBV}$ infection. It is critical to develop innovative interventions that encourage condom use and increase knowledge of HBV vaccination among MSM.

This study was supported financially by the researchers themselves. We wish to thank the participants, the bar owners, managers, and staff.

SCOTT D RHODES

Department of Health Behavior, School of Public Health, University of Alabama, Birmingham, Alabama, USA

RALPH J DICLEMENTE

Department of Behavioral Sciences and Health Education, Rollins School of Public Health, Emory University, Atlanta, Georgia, USA

LELAND J YEE

Department of Epidemiology and International Health, School of Public Health, University of Alabama, Birmingham, Alabama, USA

KENNETH C HERGENRATHER

Department of Rehabilitation, Auburn University, Auburn, Alabama, USA

Correspondence to: Ralph J DiClemente, $\mathrm{PhD}$, Rollins School of Public Health, Emory University, 1518 Clifton Road, NE; BSHE/5th Floor, Atlanta, GA 30322, USA

rdiclem@sph.emory.edu

1 Brook MG. Sexual transmission and prevention of the hepatitis viruses A-E and G. Sex Transm Inf 1998;74:395-8.

2 Seage GR 3rd, Mayer KH, Lenderking WR, et al. HIV and hepatitis B infection and risk behavior in young gay and bisexual men. Public Health Rep 1997;112:158-67.

3 Loke RH, Murray-Lyon IM, Balachandran T, et al. Screening for hepatitis $\mathrm{B}$ and vaccination of homosexual men. BMF 1989;298:234.

$4 \mathrm{Katz} M$. Undervaccination for hepatitis B among young men who have sex with men: San Francisco and Berkeley, California. MMWR 1996;45:215-7.

5 Kane M. Epidemiology of hepatitis B infection in North America. Vaccine 1995;13(Suppl in North

6 Abram SB, ed. Control of communicable diseases manual. 16 ed. Washington, DC: American Public Health Association, 1995.

Accepted for publication 17 July 2000

NOTICES

International Herpes Alliance and International Herpes Management Forum The International Herpes Alliance has introduced a website (www.herpesalliance.org) from which can be downloaded patient information leaflets. Its sister organisation the International Herpes Management Forum (website: www.IHMF.org) has launched new guidelines on the management of herpesvirus infections in pregnancy at the 9th International Congress on Infectious Disease (ICID) in Buenos Aires.

Pan-American Health Organization, regional office of the World Health Organization
A catalogue of publications is available online (www.paho.org). The monthly journal of PAHO, the Pan American Journal of Public Health, is also available (subscriptions: pubsvc@tsp.sheridan.com).

Imperial College School of Medicine, Division of Paediatrics, Obstetrics and Gynaecology, symposium on Maternal Mental Health and the Child, 12 October 2000

Further details: Symposium Office, Imperial College School of Medicine, Queen Charlotte's and Chelsea Hospital, Goldhawk Road, London W6 0XG, UK (tel: +44 (0) 20 8383 3904; fax: +44 (0) 208383 8555; email: sympreg@ic.acx.uk).

11th Regional Meeting of International Union against Sexually Transmitted Infections, South East Asian and Western Pacific Branch and 24th National Conference of Indian Association for the Study of Sexually Transmitted Diseases and AIDS, 13-15 October 2000, Chandigarh, India

Further details: Dr Bhushan Kumar, Organising Secretary, 11th Regional Meeting of IUSTI-Asia Pacific (SE Asia and W Pacific Branch), Department of Dermatology, Venereology and Leprosy, PGIMER, Chandigarh - 160 012, India (tel: +91 (0172) 745330; fax: +91 (0172) 744401/745078; email: kumarbhushan@hotmail.com).

New Zealand Venereological Society Conference, Centennial Convention Centre, Palmerston North, New Zealand, 18-20 October 2000

Ka Hikoitia Ka Korerotia Mo Te Tau Rua Mano (Maori) "Walk the Talk 2000." Further details: Sue Peck, Conference Organiser, SP Conference Management, PO Box 4400, Palmerston North, New Zealand (tel: 646 357 1466; fax 646357 1426; email suepeck@xtra.co.nz).

Imperial College School of Medicine, Division of Paediatrics, Obstetrics and Gynaecology, symposium on Women and Children with HIV and AIDS, 20 October 2000

Further details: Symposium Office, Imperial College School of Medicine, Queen Charlotte's and Chelsea Hospital, Goldhawk Road, London W6 0XG, UK (tel: +44 (0) 20 8383 3904; fax: +44 (0) 208383 8555; email: sympreg@ic.acx.uk).

Imperial College School of Medicine, Division of Paediatrics, Obstetrics and Gynaecology, symposium on key issues in the Care of Women and Gynaecological Gancers (for nurses), 30 October 2000 Further details: Symposium Office, Imperial College School of Medicine, Queen Charlotte's and Chelsea Hospital, Goldhawk Road, London W6 0XG, UK (tel: +44 (0) 20 8383 3904; fax: +44 (0) 208383 8555; email: sympreg@ic.acx.uk).

Consortium of Thai Training Institutes for STDs and AIDS-10th STDs/AIDS diploma course, Bangkok Hospital, Bangkok (30 Oct-12 Nov) and Prince of Songkla University, Hat Yai, Thailand (13-23 Nov) 30 October-23 November 2000

Further details: Hat Yai Secretariat, Dr Verapol Chandeying, Dept of OB-GYN, Faculty of Medicine, Prince of Songkla Univer- sity, Hat Yai, Songkla 90110, Thailand (fax: (66-74) 446 361; email: cverapol@ ratree.psu.ac.th or Bangkok Secretariat, Dr Thanit Palanuvej, Bangkok Hospital, 189 Sathorn Road, Bangkok 10120, Thailand (fax: (66-2) 286 3013; email: pthanit@, email.ksc.net).

Imperial College School of Medicine, Division of Paediatrics, Obstetrics and Gynaecology, revision course for DCH (at Wolfson Conference Centre), 13-17 November 2000

Further details: Symposium Office, Imperial College School of Medicine, Queen Charlotte's and Chelsea Hospital, Goldhawk Road, London W6 0XG, UK (tel: +44 (0) 20 8383 3904; fax: +44 (0) 208383 8555; email: sympreg@ic.acx.uk).

Consortium of Thai Training Institutes for STDs and AIDS-International Reunion and Refresher Course on Sexual Health, Lee Garden Plaza Hotel, Hat Yai, Thailand 24-26 November 2000

Further details: Hat Yai Secretariat, Dr Verapol Chandeying, Dept of OB-GYN, Faculty of Medicine, Prince of Songkla University, Hat Yai, Songkla 90110, Thailand (fax: (66-74) 446 361; email: cverapol@ ratree.psu.ac.th or Bangkok Secretariat, Dr Thanit Palanuvej, Bangkok Hospital, 189 Sathorn Road, Bangkok 10120, Thailand (fax: (66-2) 286 3013; email: pthanit@ email.ksc.net).

Royal Society of Medicine and National Institutes of Health International Conference, RSM London, 7-8 December 2000

The RSM in London, UK, and the NIH in Bethesda, Maryland, US, are organising an international conference to be held at the RSM on "New trends in HIV management and research." Further details: Victoria Boswell, Academic Conference Assistant, Royal Society of Medicine (tel: +44 (0) 20 7290 2965; fax:+44 (0)20 7290 2977; email: victoria.boswell@roysocmed.ac.uk).

International Symposium on Disorders of the Prostate, 21-23 March 2001, Castres, France

Further details:Dr Mike Briley, Scientific Director, Pierre Fabre Medicament, Parc Industriel de la Chartreuse, F-81106 Castres Cedex, France (tel:+33 563714 501; fax: +33 563 725; email: briley@pierrefabre.imagenet.fr).

Call for papers-6th European Forum on Quality Improvement in Health Care, 29-31 March 2001, Bologna, Italy

Further details: BMA/BMJ Conference Unit, BMA House, Tavistock Square, London WC1H 9JP, UK (tel: +44 (0) 207383 6409; fax: $+44 \quad$ (0) 207383 6869; email: quality@bma.org.uk; website: www.quality. bmjpg.com).

6th European Conference on Experimental AIDS Research (ECEAR '2001), 23-26 June 2001, Heriott-Watt University, Edinburgh, UK

Further details: ECEAR '2001 Conference Secretary, Division of Retrovirology, NIBSC, Blanche Lane, South Mimms, Potters Bar, Herts, EN6 3QG, UK. 


\section{CORRECTION}

The paper by Hughes et al "Comparison of risk factors for four sexually transmitted infections: results from a study of attenders at three genitourinary medicine clinics in England" published in the August issue of STI (2000;76:262-7) contained errors in tables 1 and 2. The correct versions of these tables are published here. The multivariable statistical analyses presented in tables 3 and 4 , on which the paper focuses and on which the discussion and conclusions are based, are unaffected by the errors and remain unchanged.

Table 1 Characteristics of patients attending three GUM clinics in England, April 1994 to September 1997

\begin{tabular}{|c|c|c|c|}
\hline & $\begin{array}{l}\text { Royal Hallamshire, } \\
\text { Sheffield }(\%)\end{array}$ & $\begin{array}{l}\text { St Thomas's, London }{ }^{2} \\
(\%)\end{array}$ & $\begin{array}{l}\text { Mortimer Market Centre } \\
(M M C), \text { London }^{3}(\%)\end{array}$ \\
\hline Total attenders & 20334 & 15155 & 15882 \\
\hline \multicolumn{4}{|l|}{ Sex: } \\
\hline Males & $9992(49)$ & $7969(53)$ & $8143(51)$ \\
\hline Females & $10314(51)$ & $7186(47)$ & $7659(48)$ \\
\hline Not recorded & $28(<1)$ & - & $80(1)$ \\
\hline \multicolumn{4}{|l|}{ Age group: } \\
\hline $13-15$ & $189(1)$ & $64(<1)$ & $20(<1)$ \\
\hline $16-19$ & 2319 (11) & $977(6)$ & $671(4)$ \\
\hline $20-24$ & $5672(28)$ & $3199(21)$ & $3390(21)$ \\
\hline $25-34$ & $7809(38)$ & $7425(49)$ & $7658(48)$ \\
\hline $35+$ & $4254(21)$ & $3485(23)$ & $4135(26)$ \\
\hline Not recorded & $91(<1)$ & $5(<1)$ & $8(<1)$ \\
\hline \multicolumn{4}{|c|}{ Male sexual orientation: } \\
\hline Heterosexual & $9181(92)$ & $6744(85)$ & $2176(27)$ \\
\hline Homo/bisexual & $800(8)$ & $1174(15)$ & $1751(22)$ \\
\hline Not recorded & $11(<1)$ & $51(1)$ & $4216(52)$ \\
\hline \multicolumn{4}{|c|}{ Female sexual orientation: } \\
\hline Heterosexual & $10145(98)$ & 7057 (98) & $4001(52)$ \\
\hline Homo/bisexual & $165(2)$ & $89(1)$ & $96(1)$ \\
\hline Not recorded & $4(<1)$ & $40(1)$ & $3562(47)$ \\
\hline \multicolumn{4}{|l|}{ Ethnic group: } \\
\hline White & $18014(89)$ & $8383(55)$ & $8629(54)$ \\
\hline Black Caribbean & $1038(5)$ & $4308(28)$ & $433(3)$ \\
\hline Black African & $140(1)$ & $1611(11)$ & $435(3)$ \\
\hline Asian & $483(2)$ & $496(3)$ & $506(3)$ \\
\hline Other/mixed ${ }^{4}$ & $297(1)$ & $357(2)$ & $498(3)$ \\
\hline Not recorded & $362(2)$ & - & $5381(34)$ \\
\hline \multicolumn{4}{|l|}{ Presenting diagnosis } \\
\hline Genital warts ${ }^{5}$ & $1976(10)$ & $963(6)$ & $619(4)$ \\
\hline Genital HSV ${ }^{5}$ & $548(3)$ & $433(3)$ & $265(2)$ \\
\hline Gonorrhoea $^{6}$ & $389(2)$ & $559(4)$ & $285(2)$ \\
\hline Chlamydia $^{6}$ & $2175(11)$ & $752(5)$ & $633(4)$ \\
\hline \multicolumn{4}{|c|}{ Number of partners ${ }^{7}$ (heterosexuals): } \\
\hline $0-1$ & $10353(53)$ & $7299(53)$ & $2897(47)$ \\
\hline 2 & $5027(26)$ & $3541(26)$ & $1611(26)$ \\
\hline $3+$ & $3961(20)$ & $2802(20)$ & 1669 (27) \\
\hline Not recorded & $13(<1)$ & $159(1)$ & - \\
\hline \multicolumn{4}{|l|}{ Previous STI: } \\
\hline Yes & $5791(28)$ & $5807(38)$ & $3483(22)$ \\
\hline Not recorded & - & $3(<1)$ & $7533(47)$ \\
\hline \multicolumn{4}{|l|}{ Ever injected drugs } \\
\hline Yes & $361(2)$ & $228(2)$ & $145(1)$ \\
\hline Not recorded & - & $2(<1)$ & $7486(47)$ \\
\hline \multicolumn{4}{|c|}{ Commercial sex work (ever): } \\
\hline Yes & $543(3)$ & - & $181(1)$ \\
\hline Not recorded & - & $15155(100)$ & $7641(48)$ \\
\hline
\end{tabular}

1 Data for 1 April 1994 to 30 September 1997

2 Data for 1 April 1994 to 31 December 1996.

3 Data for 1996 only.

4 Includes "black other."

5 First episode.

6 Uncomplicated infection.

7 Number of partners in past 12 months for Sheffield and St Thomas's clinics and in past 3 months for MMC (see methods for details).

Table 2 Numbers of attenders diagnosed with first episode genital warts, first episode genital HSV, uncomplicated gonorrhoea and uncomplicated chlamydia, showing concurrent infections, in attenders at three GUM clinics in England, April 1994 to September 1997 (+ = present, - = absent)

\begin{tabular}{llllll}
\hline No of attenders & $(\%)$ & Warts & HSV & Gonorrhoea & Chlamydia \\
\hline 3320 & $(6.46)$ & + & - & - & - \\
3101 & $(6.04)$ & - & - & - & + \\
1184 & $(2.30)$ & - & + & - & - \\
957 & $(1.86)$ & - & - & + & + \\
233 & $(0.45)$ & - & - & + & + \\
187 & $(0.36)$ & + & - & - & + \\
28 & $(0.05)$ & - & + & - & - \\
21 & $(0.04)$ & + & - & + & + \\
21 & $(0.04)$ & + & + & + & + \\
11 & $(0.02)$ & - & - & + & - \\
9 & $(0.02)$ & + & - & + & \\
2 & $(0.00)$ & - & - & & + \\
42297 & $(82.34)$ & - & & & - \\
Total 51371 & $(100)$ & & & & - \\
\hline
\end{tabular}

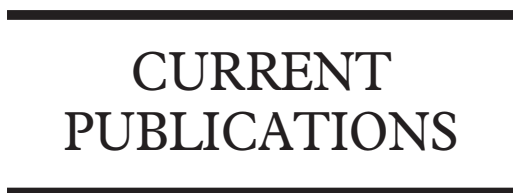

Selected titles form recent reports published worldwide are arranged in the following sections:

Gonorrhoea

Chlamydia

Candidiasis

Bacterial vaginosis

Trichomoniasis

Syphilis and other treponematoses

Hepatitis

Herpes

Human papillomavirus infection

Cervical cytology and colposcopy

Other sexually transmitted infections

Public health and social aspects

Microbiology and immunology

Dermatology

Miscellaneous

\section{Gonorrhoea}

Sexually transmitted disease clinic clients at risk for subsequent gonorrhea and chlamydia infections-possible 'core' transmitters.

Ra GunN, s Fitzgerald, so aral. Sex Transm Dis 2000;27:343-9

Gonorrhea among men who have sex with men: outbreak caused by a single genotype of erythromycin-resistant Neisseria gonorrhoeae with a singlebase pair deletion in mtrR promoter region.

MS XIA, WLH WHITTINGTON, WM SHAFER, KK Holmes. F Infect Dis 2000;181:2080-2

Amultiplex polymerase chain reaction to differentiate $\beta$-lactamase plasmids of Neisseria gonorrhoeae.

HM PALNER, JP LEENING, A TURNER. $\mathcal{F}$ Antimicrob Chemother 2000;45:777-82

A typing system for Neisseria gonorrhoeae based on biotinylated oligonucleotide probes to PIB gene variable regions.

DK THOMPSON, CD DEAL, CA IsOn et al. F Infect Dis 2000;181:1652-60

The lipopolysaccharide structures of Salmonella enterica serovar typhimurium and Neisseria gonorrhoeae determine the attachment of human mannose-binding lectin to intact organisms. M DEUYATROVAJOHNSON, IH REES, BD ROBERTSON et al. Infect Immun 2000;68:3894-9

Expression of AniA, the major anaerobically induced outer membrane protein of Neisseria gonorrhoeae, provides protection against killing by normal human sera.

JA CARDINALE, VL Clark. Infect Immun 2000;68:4368-9 


\section{Chlamydia}

Duration of untreated genital infections with Chlamydia trachomatis-a review of the literature.

MR GOLDEN, JA SCHILLINGER, L MARKOWITZ, ME STLOUIS. Sex Transm Dis 2000;27:329-37

Urogenital Chlamydia trachomatis serovars in men and women with a symptomatic or asymptomatic infection: an association with clinical manifestations? SA MORRE, L ROZENDAAL, IHM VANVALKENGOED $e t$ al. F Clin Microbiol 2000;38:2292-2301

Relationship of hormonal contraception and cervical ectopy as measured by computerized planimetry to chlamydial infection in adolescents.

DL JaCOBSON, L PERALta, M FARMer et al. Sex Transm Dis 2000;27:313-9

Pooling cervical swabs and testing by ligase chain reaction are accurate and cost-saving strategies for diagnosis of Chlamydia trachomatis.

J KAPALA, D COPES, A SPROSTON et al. $\mathcal{f}$ Clin Microbiol 2000;38:2480-3

Reproducibility problems with the Abbott Laboratories LCx assay for Chlamydia trachomatis and Neisseria gonorrhoeae.

AM GRONOWSKI, S COPPER, D BAORTO, PR MURRAY. $\mathcal{F}$ Clin Microbiol 2000;38:2416-8

An important proportion of genital samples submitted for Chlamydia trachomatis detection by PCR contain smal amounts of cellular DNA as measured by $\beta$-globin gene amplification.

F COUTLEe, M DELADURANTAYe, C TRAMblay $e t$ al. F Clin Microbiol 2000;38:2512-9

Effects of estradiol and progesterone on susceptibility and early immune responses to Chlamydia trachomatis infection in the female reproductive tract. C KAUSHIC, F ZHOU, AD MURDIN, CR WIRA. Infect Immun 2000;68:4207-16

Priming with Chlamydia trachomatis major outer membrane protein (MOMP) DNA followed by MOMP ISCOM boosting enhances protection and is associated with increased immunoglobulin $A$ and Th1 cellular immune responses.

DJ ZHANG, X YANG, CX SHEN et al. Infect Immun 2000;68:3074-8

Genetic differences in the Chlamydia trachomatis tryptophan synthase $\alpha$-subunit can explain variations in serovar pathogenesis.

AC SHAW, G CHRISTIANSEN, P ROEPSTORFF, S BIRKELUND. Microbes 2000;2:581-92

\section{Candidiasis}

Local anticandidal immune responses in a rat model on vaginal infection by and protection against Candida albicans.

F DEBERNARDIS, G SANTONI, M BOCCANERA et al. Infect Immun 2000;68:3297-3304
Role of hyphal formation in interactions of Candida albicans with endothelial cells.

QT OHAN, PH BELANGER, SG FILLER. Infect Immun 2000;68:3485-90

Measurement of T-cell-derived antigen binding molecules and immunoglobulin G specific to Candida albicans mannan in sera of patients with recurrent vulvovaginal candidiasis.

CH LitTle, gM GEORgou, a marCeglia et al. Infect Immun 2000;68:3840-7

Evidence for mating of the 'asexual' yeast Candida albicans in a mammalian host. CM HULl, RM RAISNER, AD JOHNSON. Science 2000;289:307-9

\section{Bacterial vaginosis}

The Papanicolaou smear: inadequate screening test for bacterial vaginosis during pregnancy.

JF GREene, TJ KUeHL, SR ALLen. Am $\mathcal{F}$ Obstet Gynecol 2000;182:1048-9

Identification of a human lactoferrinbinding protein in Gardnerella vaginalis. GP JAROSIK, СB LAND. Infect Immun 2000;68:3443-54

\section{Trichomoniasis}

A randomized trial of intravaginal nonoxynol 9 versus oral metronidazole in the treatment of vaginal trichomoniasis. NM ANTONelli, SJ DIEHL, JW WRIGHT. Am $\mathcal{f}$ Obstet Gynecol 2000;182:1008-10

Host and tissue specificity of Trichomonas vaginalis is not mediated by its known adhesion proteins.

MF ADDIS, P RAPPELLI, PL FIORI. Infect Immun 2000;68:4358-60

$18 S$ ribosomal DNA-based PCR for diagnosis of Trichomonas vaginalis.

H MAYTA, RH GILMAN, MM CALDERON et al. f Clin Microbiol 2000;38:2683-7

\section{Syphilis and other treponematoses}

Tracing a syphilis outbreak through cyberspace.

JD KLAUSNER, W WOLF, L FISCHERPONCE et al. FAMA 2000;284:447-9

Strategies for syphilis preventionfindings from surveys in a highincidence area.

TA FARLEY, RH KAHM, G JOHNSON, DA COHEN. Se $x$ Transm Dis 2000;27:305-10

Editorial: syphilis-a barometer of community health.

JN WASSERHEIT. Sex Transm Dis 2000;27:311-2
Use of synthetic cardiolipin and lecithin in the antigen used by the Venereal Disease Research Laboratory Test for serodiagnosis of syphilis.

AR CASTRO, WE MORRILL, WA SHAW et al. Clin Diag Lab Immunol 2000;74:658-61

Comparison of the Serodia Treponema pallidum particle agglutination, Captia syphilis-G and Spirotek Reagin II tests with standard test techniques for diagnosis of syphilis.

v POPE, MB FEARS, WE MORRILL et al. $\mathcal{f}$ Clin Microbiol 2000;38:2543-5

Treponema pallidum subsp pertenue displays pathogenic properties different from those of $T$ pallidum subsp pallidum.

$\mathrm{K}$ WICHER, $\mathrm{V}$ WICHER, F ABBRUSCATO, RE BAUGHN. Infect Immun 2000;68:3219-25

\section{Hepatitis}

Detection of hepatitis $C$ virus in the semen of infected men.

M LERUEZVILLE, JM KUNSTMANN, M DEALMEIDA et al. Lancet 2000;356:42

Heterosexual transmission of hepatitis C, hepatitis B and HIV-1 in a sample of inner-city women.

JG FELDMAN, H MINKOFF, L LANDESMAN, J DEHOviTz. Sex Transm Dis 2000;27:338-42

The natural history of hepatitis $\mathrm{C}$ virus infection-host, viral and environmental factors.

DL THOMAS, J ASTEMBORSKI, RM RAI et al. $\mathcal{F} A M A$ 2000;284:450-6

\section{Herpes}

Herpes simplex virus in the human cornea.

HS DUA. Br F Opthalmol 2000;84:560

Further evidence from a murine infection model that famciclovir interferes with the establishment of HSV-1 latent infections.

AM THACKRAy, Hu FIELD. $\mathcal{f}$ Antimicrob Chemother 2000;45:825-34

Comparison of virus isolation and various polymerase chain reaction methods in the diagnosis of mucocutaneous herpesvirus infection.

ML NOGUeIRA, JB AMORIM, Jg OLICEIRA et al. Acta Virol 2000;44:61-6

Comparison of a monoclonal antibodyblocking enzyme-linked immunoassay and a strip immunoblot assay for identifying type-specific herpes simplex virus type 2 serological responses.

GJ VANDOORNUM, MJ SLOMKA, M BULMER et al. Clin Diag Lab Immunol 2000;7:641-4

Long term persistence of herpes simplex virus-specific CD8(+) CTL in persons with frequently recurring genital herpes. CM POSAVAD, ML HUANG, S BARCY et al. F Immunol 2000;165:1146-52 
Immune protection against $\mathrm{HSV}-2$ in B-cell-deficient mice.

KL DUDLEY, N BOURNE, BN MILLIGAN. Virology 2000;270:454-63

Decreased vaginal disease in J-chaindeficient mice following herpes simplex type 2 genital infection.

BA HENDRICKSON, J GUO, I BROWN et al. Virology 2000;271:155-62

The role of the UL41 gene of herpes simplex virus type 1 in evasion of nonspecific host defence mechanisms during primary infection.

T SUZUTANI, M NAGAMINE, T SHIBAKI et al. $\mathcal{F}$ Gen Virol 2000;81:1763-72

Difference in incidence of spontaneous mutations between herpes simplex virus types 1 and 2.

RT SARISKY, TT NGUYEN, Ke DUFFy et al. Antimicrob Agents Cemother 2000;44:1524-9

\section{Human papillomavirus infection}

Quantative tests for human papillomavirus.

C JOHNSTON. Lancet 2000;355:2179

Viral load of human papillomavirus 16 as determinant for development of cervical carcinoma in situ: a nested case-control study.

AM JOSEFSSON PKE MAGNUSSON, N YLITALO et al. Lancet 2000;355:2189-93

Consistent high viral load of human papillomavirus 16 and risk of cervical carcinoma in situ: a nested case-control study.

N YLITALO, P SORENSEN, AM JOSEFSSON et al. Lancet 2000;355:2194-8

Mathematical model for the natural history of human papillomavirus infection and cervical carcinogenesis.

ER MYERS, DC MCCRORY, K NANDA et al. Am $\mathcal{f}$ Epidemiol 2000;151:1158-71

Human papillomavirus DNA testing for cervical cancer screening in lowresource settings.

L KUHN, L DENNY, A POLLACK et al. $\mathcal{F}$ Nat Cancer Inst 2000;92:818-25

Human papillomavirus testing in women with mild cytologic atypia.

C BERGERON, D JEANNEL, JD POVEDA et al. Obstet Gynecol 2000;95:821-7

Mucosal human papillomavirus types in squamous cell carcinomas of the uterine cervix and subsequently on fingers.

O FORSLUND, P NORDIN, BG HANSSON. $\mathrm{Br} \mathcal{F}$ Dermatol 2000;142:1148-53

Distribution of 37 mucosotropic HPV types in women with cytologically normal cervical smears: the age-related patterns for high-risk and low-risk types. MV JACOBS, JMM WALBOOMERS, PJF SNIJDERS et al. Int f Cancer 2000;87:221-7
Cervical neoplasia and repeated positivity of human papillomavirus infection in human immunodeficiency virusseropositive and -seronegative women. L AHDIEH, A MUNOZ, D VLAHOV et al. Am $\mathcal{F}$ Epidemiol 2000;151:1148-57

Genital human papillomavirus infection and associated penile intraepithelial neoplasia in males infected with the human immunodeficiency virus.

M GOMOUSAMICHAEL, D GIALAMA, N GOMOUSAS, g gialama. Acta Cytol 2000;44:301-4

Cost-effectiveness of screening for anal squamous intraepithelial lesions and anal cancer in human immunodeficiency virus-negative homosexual and bisexual men.

SJ GOLDIE, KM KINTZ, MC WEINSTEIN et al. Am $\mathcal{F}$ Med 2000;108:634-41

Human papillomavirus infection in atrophic smears-a case report.

R LUZZATTO, M POLI, M RECKTENVALD, L luzzatto. Acta Cytol 2000;44:420-2

Imiquimod: an immune response modifier.

f Am Acad Dermatol 2000;43:whole issue.

Correlation between pretreatment levels of interferon response genes and clinical responses to an immune response modifier (Imiquimod) in genital warts.

I ARANY, SK TYRING, MM BRYSK et al. Antimicrob Agents Chemother 2000;44:1869-73

Comparison of human papillomavirus types 16, 18 and 6 capsid antibody responses following incident infection.

J CARTER, LA KOUTSKY, JP HUGHES et al. F Infect Dis 2000;181:1911-9

Absence of antibody against human papillomavirus type $16 \mathrm{E} 6$ and $\mathrm{E} 7$ in patients with cervical cancer is independent of sequence variations.

I NINDL, K ZUMBACH, M PAWLITA et al. F Infect Dis 2000;181:1764-7

A new PCR-based assay amplifies the E6-E7 genes of most mucosal human papillomaviruses (HPV).

T SASAGAWA, y MINEMOTO, w BASHA et al. Virus Res 2000;67:127-40

The human papillomavirus type $16 \mathrm{E} 7$ oncogene is required for the productive stage of the viral life cycle.

ER FLOERS, BL ALLENHOFMANN, D LEE, PF LAMBERT. F Virol 2000;74:6622-31

Cervical lesions are associated with human papillomavirus type 16 intratypic variants that have high transcriptional activity and increases usage of common mammalian codons.

JM BIBLE, C AMNT, JM BEST et al. $\mathcal{f}$ Gen Virol 2000;81:1517-28

Minor capsid protein of human genital papillomaviruses contains subdominant, cross-neutralizing epitopes.

RBS RODEN, WH YUTZY, R FALLON et al. Virology 2000;270:254-7

Abnormalities of cornified cell envelopes isolated from human papillomavirus type 11-infected genital epithelium.

DR BROWN, JT BRYAN. Virology 2000;270:65-70
Inverse relationship between the expression of the human papillomavirus type 16 transcription factor E2 and virus DNA copy number during the progression of cervical intraepithelial neoplasia.

M STEVENSON, LC HUDSON, JE BURNS et al. $\mathcal{F}$ Gen Virol 2000;81:1825-32

8-hydroxyl-2'-deoxyguanosine in cervical cells: correlation with grade of dysplasia and human papillomavirus infection.

G ROMANO, A SGAMBATO, R MANCINI et al. Carcinogenesis 2000;21:1143-8

Immune reponses induced by BCG recombinant for human papillomavirus $\mathrm{L} 1$ and $E 7$ proteins.

IA JABBAR, GJP FERNANDO, N SAUNDERS et al. Vaccine 2000;18:2444-53

Uneven distribution of HPV 16 E6 prototype and variant $(83 \mathrm{~V})$ oncoprotein in cervical neoplastic lesions.

S ANDERSSON, M ALEMI, E RYLANDER et al. Br $\mathcal{f}$ Cancer 2000;83:307-10

Analysis of relative binding affinity of E7-pRB of human papillomavirus 16 variants using the yeast two-hybrid system.

кв Choo, ts wang, cJ HUANG. $7 \mathrm{Med}$ Virol 2000;61:298-302

The E1 helicase of human papillomavirus type 11 binds to the origin of replication with low sequence specificity.

EP DIXON, GL PAHEL, wJ ROCQUe et al. Virology 2000;270:345-57

Suprabasal expression of the human paillomavirus type 16 oncoproteins in mouse epidermis alters expression of cell cycle regulatory proteins.

JF CRISH, F BONE, S BALASUBRAMANIAN et al. Carcinogenesis 2000;21:1031-8

Induction of apoptosis in human papillomavirus-positive cancer cells by peptide aptamers targeting the viral E6 oncoprotein.

K BUTZ, C DENK, a ULlmann et al. Proc Nat Acad Sci USA 2000;97:6693-7

Binding of the human papillomavirus type $16 \mathrm{E} 7$ oncoprotein and the adenoassociated virus Rep 78 major regulatory protein in vitro and in yeast and the potential for downstream effects.

PL HERMONAT, AD SANTIN, DJ ZHAN. $\mathcal{f}$ Hum Virol 2000;3:113-24

The human papillomavirus type 16 E6 induces self-ubiquitination of the E6AP ubiquitin-protein ligase.

WH KAO, WL BEAUDENON, AL TALIS et al. $\mathcal{F}$ Virol 2000;6408-24

A functional NF- $\mathrm{KB}$ binding site in the human papillomavirus type 16 long control region.

V FONTAINE, E VANDERMEIJDEN, J DEGRAAF $e t a l$. Virology 2000;75:40-60

Identification of domains of the HPV11 E1 protein required for DNA replication in vitro.

AA AMIN, s titolo, A Pelletier et al. Virology 2000;75:137-50 


\section{Cervical cytology and colposcopy}

Management guidelines for women with normal colposcopy after low grade cervical abnormalities: population study.

GR TEALE, DD MOFFITT, CH MANN, DM LUESLEY. BMf 2000;320:1693-6

Accuracy of the Papanicolaou test in screening for and follow-up of cervical cytologic abnormalities: a systemic review.

K NANDA, DC MCCRORY, ER MYERS et al. Ann Intern Med 2000;132:810-9

The borderline cervical smear: colposcopic and biopsy outcome.

A ALNAFUSSI, G REBELLO, R ALYUSIF, E MCGoogan. F Clin Pathol 2000;53:439-44

Combined Pap smear, cervicography and HPV DNA testing in the detection of cervical intraepithelial neoplasia and cancer.

s Costa, m SIDERI, k SYRJanen $e t$ al. Acta $C y t o l$ 2000;44:310-8

Comparison of endocervical curettage and endocervical brushing.

S KLAM, J ARSENEAU, MN MANSOUR et al. Obstet Gynecol 2000;96:90-4

Laser scanning confocal microscopy of cervical tissue before and after application of acetic acid.

RA DREZEK, T COLLIER, CK BROOKNER et al. Am $\mathcal{f}$ Obstet Gynecol 2000;182:1135-9

Cervical intraepithelial neoplasia outcomes after large loop excision with clear margins.

E PARASKEVAIDIS, ED LOLIS, G KOLIOPOULOS $\mathrm{et}$ al. Obstet Gynecol 2000;95:828-31

Cyclin E expression and early cervical neoplasia in ThinPrep specimens-a feasibility study.

ej weaver, aj kovatich, m вibbo. Acta Cytol 2000;44:301-4

\section{Other sexually transmitted infections}

Features of urethritis in a cohort of male soldiers.

KT MCKEE, PR JENKINS, R GARNER et al. Clin Infect Dis 2000;30:736-41

High prevalence of Epstein-Barr virus type 2 among homosexual men is caused by sexual transmission.

D VANBAARLE, E HOVENKamp et al. $\mathcal{F}$ Infect 2000;181:2045-9

Seropositivity to human herpesvirus 8 in relation to sexual history and risk of sexually transmitted infections among women.

R TEDESCHI, L CAGGIARI, I SILINS et al. Int $\mathcal{F}$ Cancer 2000;87:232-5

\section{Public health and social aspects}

Increase in high risk sexual behaviour among homosexual men, London 1996-8: cross sectional questionnaire study.

JP DODDS, L NARDONE, DE MERCEY et al. BMF 2000;320:1510

Promotion of condom use in a high-risk setting in Nicaragua: a randomized controlled trial.

M EGGAR, J PAUW, A LOPATATZIDIS et al. Lancet 2000;355:2101-5

A randomized trial of hierarchical counseling in a short, clinic-based intervention to reduce the risk of sexually transmitted diseases in women.

EL GOLLUB, P FRENCH, A LOUNDOU et al. AIDS 2000;14:1249-56

\section{Microbiology and immunology}

Role played by lactobacilli in controlling the population of vaginal pathogens. $\mathrm{S}$ BORIS, C BARBES. Microbes Infect 2000;2:543-6

The immune responses to bacterial antigens encountered in vivo at mucosal surfaces.

G DOUGAN, M GHAEMMAGHAMI, D PICKARD $e t$ al. Phil Trans Roy Soc London 2000;355:705-15

\section{Dermatology}

Vulvitis circumscripta plasmacellularis mimicking child abuse.

SE ALBERS, G RAYLOR, D HUYER et al. $\mathcal{F} \mathrm{Am} \mathrm{Acad}$ Dermatol 2000;42:1078-80

Two cases of vulval pigmented extramammary Paget's disease: histochemical and immunohistochemical studies.

H CHiba, T Kazama, T TAKeNouchi et al. $\mathrm{Br} \mathcal{F}$ Dermatol 2000;142:1190-4

\section{Miscellaneous}

Behavioral aspects of sexually transmitted diseases-core groups and bridge populations-editorial.

SO ARAL. Sex Transm Dis 2000;27:327-8

Prevalence of sexually transmitted infections among clients of female commercial sex workers in Thailand.

SN TABRIZI, S SKov, v CHANDEYING et al. Sex Transm Dis 2000;27:358-65
Syndromic treatment of sexually transmitted diseases reduces the proportion of incident HIV infections attributable to these diseases in rural Tanzania. KK ORROTH, A GaVYole, J TODD et al. AIDS 2000;14:1429-38

Control of sexually transmitted diseases for HIV-1 prevention: understanding the implications of the Mwanza and Rakai trials.

H GROSSKURTH, R GRAY, R HAYES et al. Lancet 2000;355:1981-7

Sexually transmitted diseases and the increased risk for HIV transmission: implications for cost-effectiveness analyses of sexually transmitted disease prevention interventions.

HW CHESSON, SD PINKERTON. $\mathcal{F}$ Acq Immun Defic Synd 2000;24:48-56

The challenge of sexually transmitted diseases for the military: what has changed?

CA GAYDOS, TC QuinN, JC GaYdos. Clin Infect Dis 2000;30:719-22

Reducing risk of sexually transmitted disease and human immunodeficiency virus infection in a military STD clinic: evaluation of a randomised preventive intervention trial.

PR JENKINS, RA JENKINS, ED NANNIS et al. Clin Infect Dis 2000;30:730-5

Assessing the burden of sexual and reproductive ill-health: questions regarding the use of disability-adjusted life years.

C ABOUZAHR, JP vaUghan. Bull WHO 2000;78:655-66

Integration of prevention and care of sexually transmitted infections with family planning services: what is the evidence for public health benefits? KL DEHNE, R SNOW, KR OREILLY. Bull WHO 2000;78:628-39

Emergency contraception: advance provision in a young, high-risk clinic population.

T RAINE, C HAPER, K LEON, P DARNEY. Obstet Gynecol 2000;96:1-7

Prevalence of home pregnancy testing among adolescents.

ML SHEW, WL HELLERSTEDT, RE SIEVING et al. Am f Public Health 2000;90:974-6

Sexually transmitted diseases and sexual behaviour in men attending an outpatients' clinic for gay men in Gothenburg, Sweden.

mad Christiansen, gb lowhagen. Acta Derm Venereol 2000;80:136-9

Adverse childhood experiences and sexually transmitted diseases in men and women: a retrospective study.

SD HILLIS, RF ANDA, VJ FELITTI, D NORDENBERG, PA Marchbanks. Pediatrics 2000;106:U12U17

Identification of female cells in postcoital penile swabs using fluorescence in situ hybridisation-application in sexual assault.

Ka Collins, si Cina, mi Pettenai. Arch Pathol Lab Med 2000;124:1080-2 
Fluctuation in lower urinary tract symptoms in women-reassurance and watchful waiting can prevent overtreatment. S HUNSKAAR. BMF 2000;320:1418

Incidence and remission rates of lower urinary tract symptoms at one year in women aged 40-60: longitudinal study.

LA MOLLER, H LOSE, T JORGENSEN. BMF 2000;320:1429-31

Effect of a three month course of ciprofloxacin on the outcome of reactive arthritis.

T YLIKERTTULA, R LUUKKAINEN, U YLIKERTTULA et al. Ann Rheum Dis 2000;59:565-9

Reactive arthritis: the result of an antiidiotypic immune response to a bacterial lipopolysaccharide antigen where the idiotype has the immunological appearance of a synovial antigen.

JR KENNEDY. Med Hypotheses 2000;54:723-5

Detection of Kaposi's sarcomaassociated herpesvirus in oral and genital secretions of Zimbabwean women.

TM LAMPINEN, S KULASINGAM, JN MIN et al. $\mathcal{F}$ Infect Dis 2000;181:1785-90

Effect of intravaginal practices on the vaginal and cervical mucosa of Zimbabwean women.

JHHM VANDEWIJGERT, ZM CHIRENJE, V ILIFF $e t$ al. f Acq Immun Defic Synd 2000;24:62-7
Polyherbal formulations with wide spectrum antimicrobial activity against reproductive tract infections and sexually transmitted pathogens.

GP TALWAR, P RAGHUVANSHI, R MISHRa et al. Am f Reprod Immunol 2000;43:144-51

Bacteriology and treatment of malodorous lower reproductive tract in gynaecologic cancer patients.

VE VONGRUENIGEN, RL COleman, AJ Li et al. Obstet Gynecol 2000;96:23-7

Association of Ureaplasma urealyticum with abnormal reactive oxygen species levels and absence of leukocytospermia. JM POTTS, R SHARMA, F PASQUALOTTO et al. $\mathcal{F}$ Urol 2000;163:1775-8

Acute vulvar vestibulitis occurring during chemotherapy with cryptophycin analogue LY355703.

TM DEPAS, M MANDALA, G CURIGLIANO, F PECCATORI. Obstet Gynecol 2000;95:1030

Drug therapy: erectile dysfunction. TF LUE. N Engl f Med 2000;342:1802-13

Effect of erectile dysfunction on frequency of intercourse: a population based prevalence study in Finland.

J KOSKIMAKI, M HAKAMA, H HUHTALA, TLJ TAMMELA. $\mathcal{F}$ Urol 2000;164:367-70
Peyronie's disease: etiology, medical and surgical therapy.

wjg hellstrom, tj Bivalaceua. $\mathcal{F}$ Andrology 2000;21:347-55

Evidence based assessment of long-term results of plaque incision and vein grafting for Peyronie's disease.

F MONTORSI, A SALONIA, T MAGA et al. $\mathcal{F}$ Urol 2000;163:1704-8

Safety and acceptability of a baggy latex condom.

M MACALUSO, R BLACKWELL, B CARR et al. Contraception 2000;61:217-24

Tuberculosis of the penis after intravesical bacillus Calmette-Guerin treatment. JM LATINI, DS WANG, P FORGACS, W BIHRIE. $\mathcal{F}$ Urol 2000;163:1870

Clinical management of foreign bodies of the genitourinary tract.

A VANOPHOVEN, JB DEKERNION. $\mathcal{f}$ Urol 2000;164:274-87

Genital diseases in the Peruvian dusky dolphin (Lagenorhynchus obscurus). MF VANBRESSEM, K VANWAEREBEEK, U SIEBERT et al. F Comparative Pathol 2000;122:266-77

Scrotal dog bites.

JM CUMMINGS, JA BOULLIER. $\mathcal{f}$ Urol 2000;164:57-8 